total cost of building the telescope and operating it for its projected 15-year lifetime could amount to $\$ 1,400$ million. "The country faces an $\$ 80$ billion deficit, and it is time the Congress said 'no'. The space telescope is a good place to start", said Proxmire.

The GAO essentially took NASA's estimate for $\$ 435$ million to develop the LST, and added \$96 million for inflation, \$65 million for tracking and data acquisition, $\$ 470$ million for general operations costs, $\$ 81$ million for civil service personnel, and $\$ 211$ million for shuttle launches to put the instrument into orbit and to refurbish and maintain it.

The GAO figures have sent NASA officials into orbit. In a letter printed in the GAO report, Noel Hinners, Associate NASA Administrator for Space Science, charged that "presenting this eclectic array of cost data as a life-cycle cost estimate for the space telescope is misleading". In an interview with Nature last week, Hinners said that NASA is still estimating that the development cost for the LST will be about $\$ 435$ million, and that the operations costs will be about \$10$\$ 15$ million a year. The operating estimates do not include shuttle launch and refurbishment, he acknowledged, because it is not known how frequently the telescope will be visited for maintenance.

Hinners argued that the operating cost for the LST will not be much different from the $\$ 10$ million it costs to operate a major ground-based facility such as Kitt Peak. "I don't see anybody saying that if Kitt Peak lasts for 100 years it will cost \$1 billion", Hinners wryly observed.

Nevertheless, whatever the accuracy of the GAO figures, the report highlights the fact that the cost of the LST will not end with the launch, and the figure of $\$ 1,400$ million is sure to be a powerful weapon in Proxmire's hands. Few people are willing to predict the outcome in the Senate for, although Proxmire has failed to sway his committee against NASA proiects in the past, there has been a significant change of membership on his committee this year. Two staunch supporters of the space programme, Lawton Chiles of Florida and Bennett Johnston of Louisiana, have been replaced by James Sasser of Tennessee and Patrick Leahy of Vermont, both of whom are fiscal conservatives. Even if he loses in committee, however, Proxmire is expected to take his fight to the Senate floor.

According to committee sources Proxmire is concentrating on the LST at this stage, and is probably prepared to approve funds for the Jupiter Orbiter Probe (JOP). But the sources suggest that if Proxmire loses on the LST, he may then turn on the Jupiter project. NASA officials would regard loss of that project as a body blow for the planetary science programme in general and to the Jet Propulsion Laboratory in particular. If both the House and Senate delete funds for the project, there would be no chance to reinstate them in conference committees.

At present, there is only one approved planetary mission under way. That is the so-called Voyager project which involves launching spacecraft in August this year to flit past Jupiter and travel on to Saturn. One of the spacecraft may also be re-targeted to swing past Uranus eight years after launch. Thus, if the JOP is not approved, there would be a major hiatus in the planetary programme, with no projects under development at all. According to NASA officials, up to 300 people would be laid off at the JPL, which is now the focus of NASA's planetary work. It should be noted that if the 1982 launch date is missed, there would not be another good opportunity until 1987, because Jupiter will be too far away.

Again, NASA officials argue that if the JOP is killed, planetary science teams would be broken up, and the continuity between programmes would be lost. The technology used on the Pioneer Venus probes would be adapted to the JOP mission, and the JOP spacecraft technology would in turn be used on the planned out-of-ecliptic mission. If there is a major disruption in the planetary programme, "we would lose that inheritance from one mission to the next", Hinners says.

NASA officials are taking those arguments to Senators now in the hope of building support for the efforts. Though the prospects are difficult to assess, it is expected that the LST will scrape through in the Senate, and that the Senate will also approve some funds for the JOP. If those decisions are upheld in the conference committee, NASA would be able to start work on JOP next year, and avoid maior layoffs.

Finally, it should be noted that the reason why these projects are deemed especially crucial this year is because some space science proiects have been squeezed out of NASA's budget during the past four years to accommodate funding for the space shuttle. Space scientists have been assuming, however, that when funding for the shuttle begins to run down, more money would be made available for space science. Next year is the first year of reduced shuttle funding, but science projects are still at the front of the firing line.

\section{DNA bills drafted}

UNDER intense lobbying from a number of scientists, committee staff members in the House and Senate have put together draft versions of legislation to control recombinant DNA research in the United States. Though there are still plenty of opportunities for the drafts to be altered by the committees themselves, major differences are shaping up in the approaches embodied in the House and Senate versions. The draft Senate bill, in particular, is causing consternation among many scientists.

The House bill has already been approved in principle by the health subcommittee of the House Commerce committee, and members of the subcommittee are expected to meet next week to approve the final wording. It will then go to the full committee for approval before being sent to the floor of the House. The Senate version has not progressed that far. It has been drafted by staff members of the health subcommittee, though it is said to reflect the views of the subcommittee chairman Edward Kennedy, and it will not be considered by the committee itself until next week at the earliest.

The House draft would require the Secretary of Health, Education and Welfare (HEW) to draw up new recombinant DNA regulations, with the advice of a top-level advisory committee, and to licence facilities where such experiments are to be conducted. The bill would leave much of the implication of the regulations, including the granting of most licences, to local biohazards committees, however. Consisting mostly of scientists, the committees would include lay members and representatives of local communities. The Senate version, on the other hand, would establish an eleven-member commission in HEW to draft regulations and issue licences for facilities and for individual experiments. Both versions imply that, until new regulations are adopted, guidelines issued last year by the National Institutes of Health would be given the force of law.

The Senate approach has come under heavy fire by scientists, most conspicuously in a resolution approved late last month by the National Academy of Sciences, for fear that it would lead to bureaucratic delays and subiect the research to inordinate red tape.

One of the most controversial issues in the debate on federal legislation has been whether state and local governments should be allowed to establish local controls which are more strict than the federal regulations. The draft House bill would allow them to do so only if they can prove to the Secretary of HEW that there are compelling local reasons for stricter controls, or that the federal regulations are not strict enough to protect public health, reauirements which come close to making the federal controls paramount. In the Senate, Kennedy is said to favour allowing state governments to set stricter controls, though some other memhers of his subcommittee favour the House approach and agreement has yet to be reached.

Colin Norman 